\title{
De Milagres e Espetáculos: 0 Ciclo Vicioso do Eterno País do Futuro
}

\author{
Ivan Colangelo Salomão e Karlo Marques Junior ${ }^{2}$ \\ ${ }^{1}$ Universidade Federal do Rio Grande do Sul (UFRGS), Porto Alegre, RS, Brasil (e-mail: \\ ivansalomao@gmail.com); \\ ${ }^{2}$ Universidade Estadual de Ponta Grossa (UEPG), Ponta Grossa, PR, Brasil (e-mail: \\ karlomjunior@hotmail.com)
}

\section{INTRODUÇÃO}

mbora já se tenha discorrido largamente acerca da suposta repeti-

¿ ção de acontecimentos históricos, muito poderia se depreender do pródigo caso nacional para que, da tragédia original, se evitasse a reincidência farsesca do segundo ato. Premonitório ou não, o adágio consagrado pelo pensador prussiano em O 18 de Brumário de Luís Bonaparte encontra na trajetória recente da economia brasileira um de seus mais eloquentes testemunhos. Dois dos mais festejados períodos de crescimento econômico observados na história do Brasil contemporâneo guardam entre si semelhanças expressivas, as quais não apenas extrapolam o misticismo dos referidos epítetos como dificilmente poderiam ser delegadas ao acaso.

Com base nessa digressão preambular, pretende-se argumentar que a analogia entre o período consagrado na literatura como "milagre econômico" (1968-1973) e o assim denominado "espetáculo do crescimento" da segunda metade dos anos 2000 revela ensinamentos que não deveriam ser desprezados nem pelos policymakers hodiernos nem pelos cientistas sociais que se incumbem da tarefa de interpretar o Brasil do século XXI.

O primeiro pilar de sustentação do robusto crescimento do PIB verificado em ambos os períodos remete às reformas institucionais levadas a cabo nos respectivos governos anteriores. As ações contidas no Plano

DADOS - Revista de Ciências Sociais, Rio de Janeiro, vol. 61, no 3, 2018, pp. 735 a 772.

http://dx.doi.org/10.1590/001152582018172 
Ivan Colangelo Salomão e Karlo Marques Junior

de Ação Econômica do Governo (PAEG) ensejaram as condições para a forte aceleração da atividade econômica registrada posteriormente. Medidas restritivas e impopulares - tais como uma abrupta redução do déficit público, uma reforma tributária regressiva e uma política de arrocho salarial - lograram assentar a inflação a patamares condizentes com as expectativas do empresariado e, principalmente, dos consumidores. Além disso, um contexto externo simpático ao financiamento das economias ditas do Terceiro Mundo moldou a conjuntura em que se assistiu às mais altas taxas de crescimento estatisticamente documentadas no país.

Cenário de similitude inquietante pôde ser observado a partir de meados da década de 2000. Em primeiro lugar, a estabilização monetária viabilizada pelo Plano Real responde por parcela evidente do desempenho econômico do período imediatamente posterior. Além disso, deve-se conferir a outras medidas de alcance comparável o êxito do crescimento recente. $\mathrm{O}$ ajuste nas contas públicas viabilizado pela Lei de Responsabilidade Fiscal, a manutenção da estabilidade via geração de superávit primário e o ganho de produtividade decorrente da privatização de setores-chave da economia nacional não devem ser negligenciados. Por fim, a mesma docilidade com que o mercado internacional brindou o generalato no início dos anos 1970 presenteou o governo que assumiu o país em 2003 por quase uma década. Se não mais através do financiamento do déficit em transações correntes especificamente, agora pelo aumento vertiginoso da demanda (e dos preços) das principais commodities exportadas pelo Brasil.

Em comum, o corolário inevitável a ambos os casos: a sucumbência da magia ao primeiro óbice externo. Tratou-se, este, do enredo observado tanto após o choque do petróleo de 1973 quanto no decorrer da crise financeira internacional deflagrada em 2008. Faz-se pedagógico, pois, analisar as especificidades do périplo vicioso que acomete a economia brasileira desde, pelo menos, meados do século XX.

Nesse sentido, intenta-se identificar padrões similares de políticas econômicas entre os dois períodos históricos supracitados: a implementação de ajustes fiscal e monetário e de reformas institucionais estabeleceu os alicerces para um ínterim de crescimento expressivo com relativa estabilidade de preços. A subsequente adoção de políticas intertemporalmente inconsistentes e com viés inflacionário - instrumentalizadas por ampla intervenção estatal no domínio econômico - acar- 
retou, por seu turno, as instabilidades macro e microeconômicas as quais resultaram em duas das mais severas crises econômicas por que já passou o país.

Isto posto, este artigo tem por objetivo ilustrar e agregar um novo elemento à já consagrada fórmula "Campos Sales-Rodrigues Alves" ${ }^{1}$. Uma vez estabilizada a economia, sucumbe-se à adoção de políticas expansionistas para além do permitido pela segunda fase do ciclo, cujas consequências onerosas, por sua vez, impõem o retorno ao início do circuito. De forma sintetizada, tem-se: (1) ajuste e estabilização; (2) "crescimento responsável"; (3) intervenção e "crescimento forçado"; e (4) retorno inevitável à primeira etapa.

Para tanto, dividiu-se o artigo em quatro partes, além desta breve introdução. Na seção dois, discorre-se acerca do período entre o PAEG (1964-1967) e o ajuste recessivo da primeira metade da década de 1980. A seguir, disserta-se sobre o intervalo compreendido entre o Plano Real e a adoção das medidas restritivas a partir do primeiro semestre de 2015. Na quarta parte, analisam-se a lógica e, mormente, as consequências do ciclo à luz de modelos teóricos populistas e novo-keynesianos. Por fim, tecem-se as considerações finais.

\section{A POLÍTICA ECONÔMICA NO REGIME MILITAR (1964-1985)}

O golpe militar de 1964 instaurou não apenas uma nova era da política brasileira, como também inaugurou outro modelo de gestão da política econômica. A centralização do poder permitiu que o governo levasse a cabo uma série de medidas impopulares durante os primeiros três anos do regime, as quais ensejaram o vigoroso crescimento do PIB observado a partir do final dos anos 1960. Prometia-se encerrar a política populista que vigorara até o início daquela década, à qual governo autoritário delegava os desequilíbrios macroeconômicos da conjuntura corrente (FONSECA, 2004).

A estagflação observada desde 1962 impunha a superação conjunta de dois problemas de difícil coadunação no curto prazo: combater a inflação de forma concomitante à adoção de políticas de estímulo à atividade econômica. A equipe de tecnocratas que assumiu o comando da economia - Octávio Gouveia de Bulhões, na Fazenda, e Roberto Campos no recém-criado Ministério Extraordinário para o Planejamento e Coordenação Econômica - impôs uma política econômica austera, instru-

DADOS - Revista de Ciências Sociais, Rio de Janeiro, vol. 61, n 3, 2018 
Ivan Colangelo Salomão e Karlo Marques Junior

mentalizada pelas medidas contidas no PAEG, além de duas reformulações institucionais: as reformas tributária e financeira.

\section{O Plano de Ação Econômica do Governo (PAEG)}

No que concerne à inflação, o diagnóstico apontava para o excesso de demanda causado pela monetização dos déficits públicos, pela expansão do crédito e, principalmente, pelo aumento real dos salários, os quais seriam, na visão da equipe econômica, os únicos preços não defasados àquele momento. Diferentemente do que havia sido proposto no Plano Trienal, a estratégia de estabilização monetária do PAEG pretendia-se gradualista, uma vez que uma recessão abrupta contrariava os próprios interesses do capital, classe que havia patrocinado a interrupção democrática.

Prevendo reduzir a inflação de 70\% para 10\% em 1966, adotou-se uma estratégia de contenção do salário real, cujo reajuste passou a ser calculado pela média (e não mais pelo pico) ${ }^{2}$. Do ponto de vista fiscal, estipularam-se metas para o aumento da receita e a contenção de despesas. Quanto à política monetária, previa-se atingir taxas decrescentes dos meios de pagamento e um forte controle de crédito ao setor privado.

Concomitantemente, o governo promoveu duas importantes reformas estruturais que se provaram fundamentais para embasar o crescimento econômico observado a partir de 1968. A reforma financeira inaugurou uma nova estratégia de lidar com a inflação ao instituir a correção monetária ${ }^{3}$. Buscava-se uma convivência harmoniosa com a elevação generalizada dos preços, o que, por sua vez, acabava por penalizar os setores incapazes de reajustar seus preços com base na inflação passada, notadamente, os trabalhadores pouco organizados do ponto de vista político e sindical. Nas palavras de Hermann (2011, p. 53), tratava-se de uma "mágica" da conciliação entre gradualismo e crescimento.

Além disso, procurou-se dotar o sistema financeiro brasileiro de mecanismos de financiamento de longo prazo que alicerçassem o processo de industrialização em curso. Para tanto, reestruturou-se seu arcabouço institucional, delegando as incumbências de autoridade monetária ao recém-criado Banco Central e ao Conselho Monetário Nacional. Tratou-se, ainda, de oferecer benefícios ao capital estrangeiro ao se facilitar a captação no mercado financeiro internacional, bem como o envio de lucros ao exterior. 
De milagres e espetáculos: o ciclo vicioso do eterno país do futuro

Por fim, com intuito de atenuar um antigo entrave institucional sob a ótica do capital, o governo extinguiu a antiga estabilidade laboral a qual vigia no país havia anos. Como forma de recompensar os trabalhadores, criou-se o Fundo de Garantia do Tempo de Serviço (FGTS), uma poupança forçada destinada ao financiamento de obras sociais e de infra-estrutura, e que poderia ser resgatada em determinadas situações de interesse do trabalhador.

Já a reforma tributária promoveu um típico ajuste fiscal recessionista, aumentando a arrecadação ao mesmo tempo em que a centralizava no governo federal - movimento de sístole (e diástole) consagrado na oportuna analogia de Sola e Kugelmas (1998). Dentre as suas principais medidas, destacam-se: (1) redefinição do espaço tributário entre as diversas esferas do governo; (2) instituição da arrecadação de impostos através da rede bancária; (3) transformação de impostos em cascata em impostos sobre valor adicionado, tais como ISS, ICM e IPI, além de fundos parafiscais, como o já citado FGTS e o PIS; e (4) ampliação da base de incidência do IRPF.

Além disso, o governo empreendeu esforços no sentido de estreitar laços com organismos financeiros internacionais e azeitar as transações econômicas com o estrangeiro. Neste sentido, incentivaram-se as exportações através de incentivos fiscais e da unificação e simplificação das taxas de câmbio, as quais passaram a ser desvalorizadas periodicamente - estratégia conhecida como crawling peg, a qual veio a ser posteriormente aprofundada - a fim de evitar uma sobrevalorização real.

Conquanto as metas de controle monetário e de inflação não tenham sido atingidas, as medidas do PAEG não depuseram contra o crescimento da economia brasileira no período, a qual registrou um avanço médio de aproximadamente $4 \%$ ao ano até 1967.

\section{O “milagre" econômico (1968-1973)}

O gabinete do segundo governo militar (1967-1969) foi alterado assim que o general Artur da Costa e Silva assumiu a Presidência da República. À testa da economia

nomeou-se o então secretário da Fazenda de São Paulo e professor de Economia da Universidade de São Paulo, Antonio Delfim Netto ${ }^{4}$, cuja gestão estendeu-se até o final do mandato do presidente Emílio Garrastazu Médici (1973).

DADOS - Revista de Ciências Sociais, Rio de Janeiro, vol. 61, n 3, 2018 
Ivan Colangelo Salomão e Karlo Marques Junior

A partir de então, promoveram-se mudanças expressivas na condução da política econômica. Em primeiro lugar, identificou-se na resiliente pressão inflacionária um caráter eminentemente de custo. Diante da capacidade ociosa herdada do período anterior, aquele diagnóstico permitiu ao ministro imprimir um caráter fortemente expansionista nas políticas fiscal e, principalmente, monetária, passando a estimular a demanda agregada através de todos os seus componentes: consumo privado, investimentos, dispêndios públicos e exportações.

Com este propósito, o governo lançou, em meados de 1968, o Plano Estratégico de Desenvolvimento (PED), cujas diretrizes vieram a emoldurar o chamado "milagre econômico brasileiro" - período de mais forte crescimento registrado na história estatisticamente registrada do país (média de aproximadamente $11 \%$ a.a.). Dentre as principais medidas do plano, destacam-se o fortalecimento da empresa privada, a consolidação da infra-estrutura, o aumento das transações comerciais com o exterior e a ampliação do mercado interno, principalmente o voltado para bens de consumo durável.

O crescimento econômico alcançado foi abertamente influenciado pela intervenção do Estado. Em primeiro lugar, o combate à inflação foi instrumentalizado pelo controle direto do governo sobre os principais preços macroeconômicos: câmbio, juros, salários e tarifas. Delegou-se tal incumbência a dois órgãos diretamente responsabilizados pela fiscalização do tabelamento: a Comissão Nacional de Estímulo à Estabilização de Preços (CONEP) e o Conselho Interministerial de Preços (CIP). Além disso, as empresas estatais estiveram diretamente relacionadas ao expressivo impulso no investimento observado no período ${ }^{5}$ : mais de $50 \%$ da formação bruta de capital fixo realizada naquele momento esteve a cargo das empresas controladas pelo governo.

Do ponto de vista do processo de industrialização, o governo intensificou a substituição de importações, com destaque para os setores de bens de consumo duráveis e de capital, fortemente apoiada no fluxo de investimento estrangeiro direto (IED). Com efeito, a conjuntura externa beneficiou o aprofundamento PSI, de modo que a maciça captação de recursos no sistema financeiro internacional ${ }^{6}$ concorreu sobremaneira para o sucesso dos desígnios do governo. Mas além de financiar o estabelecimento de novas plantas industriais - nacionais e estrangeiras -, o crescimento vultoso do comércio internacional que se 
fazia observar desde a década anterior contribuiu para um aumento de $330 \%$ nas exportações.

Justifica-se o codinome místico oferecido à primeira passagem de Delfim Netto pelo Ministério da Fazenda em virtude da conciliação de três fenômenos não apenas de difícil harmonização, como de rara observação na história da economia brasileira no século XX: além do vistoso crescimento do produto, verificou-se uma queda moderada da inflação e uma sensível melhora nas contas externas.

Não se deve deixar de apontar, contudo, o lado menos benfazejo do período: a sabida concentração de renda observada esteve diretamente associada à política de arrocho salarial patrocinada pelo governo. Ao impedir o reajuste real dos salários, o governo limitou a expansão do poder de compra das classes mais baixas justamente para favorecer a geração de poupança que fizesse frente às necessidades de investimento. O bônus oferecido ao capital pela instrumentalização da famigerada "teoria do bolo" foi definido pelo economista chileno Fernando Fajnzylber através de predicado menos indulgente: "competitividade espúria."

\section{O II PND e a opção nacional-desenvolvimentista (1975-1979)}

O fim do período posteriormente alcunhado como o "milagre econômico" não viria desacompanhado de consequências onerosas. $\mathrm{O}$ vigoroso crescimento econômico que justificou a designação alegórica implicou um expressivo aumento da dependência externa do país. A ampliação da capacidade produtiva - com destaque para o setor de bens de consumo duráveis - resultou em demanda por petróleo e bens de capital que já não mais poderia ser atendida pelo parque industrial brasileiro, subordinando, pois, o crescimento da economia à sua capacidade de importação.

Na primeira metade dos anos 1970, a primeira crise do petróleo impôs condicionalidades severas ao desempenho futuro da economia brasileira. O salto no preço do combustível desencadeou aumento da taxa de juros nos países industrializados já em 1974, medida em parte responsável pela relativa queda da atividade econômica observada no biênio subsequente. A decorrente contração das exportações brasileiras impediu a geração suficiente de divisas para que se mantivessem os níveis de importação de insumos. 
Ivan Colangelo Salomão e Karlo Marques Junior

Tal cenário de restrição foi aliviado pela maciça entrada dos chamados "petrodólares" no mercado financeiro internacional e pela percepção de que o Brasil representava um devedor seguro e confiável por parte dos agentes intermediários. Conforme assinala Carneiro (1992), a abundância de liquidez permitiu que os déficits em conta-corrente fossem financiados sem que houvesse percepção real do quadro dramático que se avistava, elevando a já vultosa dívida externa brasileira e contribuindo para reforçar a vulnerabilidade da economia do país em relação aos credores externos.

Diante desse cenário de dependência, o governo empossado em março de 1974 deparava-se com duas alternativas para materializar o ajuste externo que se mostrava inevitável. A dicotomia parcialmente imposta pelo primeiro choque do petróleo pode ser resumida pelas seguintes opções necessariamente excludentes: ajustamento ou financiamento. A primeira atrelaria o crescimento do PIB às condições do mercado internacional, o que permitiria à economia um crescimento somente quando liderado pelas exportações. Já o financiamento buscaria a possível desvinculação do cenário externo ao se investir na ampliação da capacidade de produção doméstica de energia e de bens de capital. $\mathrm{O}$ ajustamento caracterizar-se-ia por um modelo conjuntural e potencialmente recessivo, pressupondo, dessa forma, a provisoriedade da crise: tratar-se-ia de vicissitude temporal e não repetitiva. A segunda alternativa apostava em uma ousada estratégia de adaptação estrutural baseada na endogenização da oferta de insumos industriais e no aumento das exportações. Contudo, ambas estariam sujeitas, em algum grau, ao aval do mercado financeiro internacional (HERMANN, 2011).

A despeito da reticência do então ministro da Fazenda, Mário Henrique Simonsen, em relação à alternativa otimista que rejeitava qualquer intervalo recessivo, havia fatores extra-econômicos que viriam a embasar a opção pelo ajuste estrutural ${ }^{7}$. Além da forte demanda empresarial pela continuidade do crescimento econômico - uma vez que haviam sido concretizados investimentos robustos durante o período do "milagre", a maioria dos quais ainda em fase de maturação-, a credibilidade econômica requerida por um governo que se arvorara pelo delicado processo de abertura política muito contribuiu para esta decisão. Neste sentido é que não se pode negar uma manifesta vontade política ao se avalizar um plano de tamanha envergadura. Conforme destaca Sallum Junior (1996), uma resposta ortodoxa à crise conduziria a restrições econômicas imediatas, acirraria os conflitos distributivos e 
reduziria muito as possibilidades de o governo promover com sucesso a distensão política em que se empenhara.

Assim, a alternativa adotada foi concretizada pelo lançamento do II Plano Nacional de Desenvolvimento (II PND). Tratava-se de um audacioso pacote de investimentos públicos e privados direcionados a setores identificados como "pontos de estrangulamento", tais como: exportação, infra-estrutura, bens de capital e insumos básicos, com destaque para metalurgia e petroquímica. A ousadia do plano foi precisamente resumida por Tavares e Assis (1985, p. 43):

Pretendia-se nada menos do que, de forma simultânea, concluir o ciclo de instalação da indústria pesada, acabar de internar a indústria de bens de capital e completar o parque industrial de insumos básicos e de bens intermediários; além de expandir os serviços de infraestrutura nos setores de energia, transportes e telecomunicações.

O financiamento das obras, principal motivo pelo qual o plano se fazia proibitivo para o chamado grupo ortodoxo da equipe econômica, contou com a ampla disponibilidade de crédito no mercado financeiro internacional. Para Carneiro (1992, p. 298), as autoridades brasileiras não demonstravam conhecimento das novas restrições impostas pelo primeiro choque do petróleo. Caso o tivessem feito, "certamente a imagem da ilha de prosperidade, que só cairia no ridículo com a brusca desaceleração das exportações em 1975, não constituiria [...] o deleite da oposição ao regime."

Para os entusiastas do modelo adotado, as implicações negativas do programa deveriam ser assaz mitigadas se comparadas a seus dividendos positivos. Sem negar a escalada da dívida externa desencadeada pelo plano, Castro (1985) argumenta que, diante da crise que se avistava, de nada adiantaria contrair ou desaquecer a economia deixando a estrutura produtiva intactamente vulnerável. Para este autor, a "opção de 74" não consistia em adiar problemas e postergar soluções; sua negativa, sim, é que o faria. Em prosa alarmante, atestava que "travar a economia em 1974, depois de crescer $14 \%$ no ano anterior [...] equivaleria a promover o desmoronamento do presente e o comprometimento do futuro." Nas palavras de João Paulo dos Reis Velloso, então

Secretário do Planejamento e responsável direto pela implantação do II PND, "a crise do petróleo apenas tornou o programa de 1974 imperioso e inadiável." (apud CASTRO, 1985, p. 32). 
Ivan Colangelo Salomão e Karlo Marques Junior

A visão de Castro é compartilhada por diversos outros economistas de tradição estruturalista. Apesar de avalizar suas considerações, Lessa (1978), por exemplo, retrata o modelo desenvolvimentista dos anos 1970 sob uma ótica sensivelmente distinta. Para este, a racionalidade política permeou a opção adotada pelo governo Geisel. Ao afirmar que “o II PND faz da crise do petróleo a justificativa para a proclamação serena e não traumática do projeto de potência nascida no interior do aparelho do Estado", Lessa (1978) delega a estratégia adotada a motivos alheios à necessidade de internalização da estrutura produtiva de insumos básicos e de bens de capital.

Por outro lado, diversos são os analistas cujas apreciações acentuam apenas os aspectos negativos do II PND. Para Moura (1990), a opção adotada a partir de 1974 representou retrocesso irreparável para o processo de ajustamento externo da economia. Na sua visão, "a política implementada pelo governo brasileiro ampliou em boa medida o desequilíbrio da economia, acentuando sua notória vulnerabilidade externa." O autor confere à atuação governamental motivação apenas conjuntural ao resumi-la como "um exercício visando a acomodar objetivos econômicos conflitantes a curto prazo", o qual teria "simplesmente transferido para o futuro o momento de enfrentar os encargos crescentes das obrigações internacionais." (MOURA, 1990, p. 41).

Ainda assim, os resultados positivos do ajuste externo adotado pelo governo Geisel podem ser sumarizados em três diferentes aspectos: o avanço do processo de substituição de importações, a redução da dependência externa em relação ao petróleo e o aumento na diversificação das exportações de bens manufaturados. No curto prazo, a elevada taxa média de crescimento atingida entre 1974 e 1979 (aproximadamente $7 \%$ a.a.), garantida em grande parte pelo plano estatal, corroborou as expectativas não-recessivas do governo.

Já os desdobramentos negativos do audaz plano de investimentos constituem um dos raros consensos entre os analistas. Com efeito, o II PND contribuiu em larga escala para o recrudescimento da situação das contas externas, situação que esteve na base do agravamento dos conflitos distributivos e da aceleração inflacionária dos anos $1980^{8} . \mathrm{Na}$ versão friedmaniana dos fatos, por que seria o Brasil eximido da obrigatoriedade de pagar pelo almoço?

\section{O ajuste recessivo dos anos 1980}

Tão logo assumiu a Presidência da República, em março de 1979, o general João Baptista Figueiredo reagiu preventivamente à crise externa 
que se avizinhava ao nomear novamente Mário Henrique Simonsen para a Secretaria do Planejamento. Após seis meses de tentativas frustradas de impor uma agenda econômica de austeridade, as imperiosidades políticas subjacentes a um governo impopular precipitaram a demissão do ministro em agosto de 1979. Seduzido pela promessa de um novo espasmo milagroso ${ }^{9}$, o presidente da República realocou o ministro Antonio Delfim Netto da pasta da Agricultura para o comando central da política econômica.

Os resultados negativos das contas externas, aliados à crescente contundência da crise internacional, não mais permitia ao governo optar por um modelo desenvolvimentista. Para a equipe econômica, o ajuste contracionista fazia-se imperativo e inadiável. A partir de 1981, crescimento econômico passou a ser objetivo secundário. O gargalo externo passou a ocupar todas as preocupações dos tecnocratas.

Conforme destaca Carneiro (1992), o discurso oficial passou a ser marcado, então, por uma demonstração contínua de "fé ortodoxa" nos controles de demanda. Segundo o governo, os motivos para a abrupta alteração de rumos não foram outros senão os desdobramentos da crise internacional. Veladamente, porém, já se faziam representados os interesses dos credores externos na nova conduta da SEPLAN. De acordo com Moura (1990, p. 46), a mudança na política econômica em 1980 "não resultou da força da competição de grupos políticos organizados, mas sim das pressões emanadas do sistema financeiro internacional privado."

Como prova da inevitabilidade da adoção de uma nova agenda, o governo anunciava a suposta decisão tomada por parte dos bancos internacionais de restringir a oferta de fundos ao Brasil. A fim de justificar a aceitação da terapia convencional, o ministro Delfim Netto apregoava que "o processo de ajuste [teria que ser] exatamente o mesmo em todos os países." (apud CASTRO, 1985, p. 17).

Compunham o pacote recessivo lançado em 1981 os seguintes elementos de cunho ortodoxo: (1) contenção do déficit público mediante redução dos gastos de custeio, de investimentos e das transferências; (2) restrição abrupta do crédito bancário e manutenção de altas taxas de juros reais; (3) mudança na política salarial que, aliada às altas taxas de desemprego, resultou em forte diminuição da demanda interna; (4) forte desvalorização da taxa real de câmbio; (5) realismo tarifário para 
os serviços públicos; e (6) liberação de preços sujeitos ao controle aliado ao relaxamento dos critérios de similaridade.

A fim de não se mostrar fragilizado durante as eleições do Congresso Nacional imbuído de eleger o próximo presidente da República ${ }^{10}$, o governo postergou qualquer anúncio de aproximação com o Fundo Monetário Internacional para depois das eleições de outubro de 1982. Dias após o pleito, enquanto ainda se contabilizavam os votos nas urnas, o ministro Delfim Netto assumiu, enfim, estar em negociação com o Fundo, rendição esta que procurava evitar a total ruptura com o sistema financeiro internacional.

No período compreendido entre os primeiros contatos com o FMI até o final de 1983, início da fugaz recuperação econômica, verificou-se a ocorrência de três fenômenos simultâneos: a eliminação do déficit em transações correntes, a contenção do crescimento da dívida externa e a recomposição das reservas internacionais sob posse do Banco Central. $\mathrm{O}$ ano de 1984 foi o primeiro, desde o princípio do governo Figueiredo, sem que a restrição externa se apresentasse como um fator proibitivo ao crescimento econômico. Para este resultado, provaram-se essenciais, entre outros motivos secundários, a retomada da demanda dos EUA, a recuperação econômica na América Latina, os estímulos derivados da política cambial e a queda das importações de determinados produtos.

No decorrer dos três anos que restavam ao último governo militar, foram sete as cartas de intenções enviadas pelas autoridades brasileiras à diretoria do Fundo. A maior parte dos rígidos compromissos assumidos foi, contudo, solenemente descumprida. Até para os economistas do governo soavam demasiadamente draconianas as imposições feitas pelo organismo multilateral. A recessão amargada pelo país em 1983 resultou em arrocho salarial incisivo para os trabalhadores brasileiros. No ano seguinte, o superávit comercial de US\$ 12 bilhões foi alcançado através de condições ainda mais humilhantes, a ponto de o reconhecidamente contido presidente do Banco Central àquele momento, Carlos Langoni, assumir que "a política econômica que vem sendo adotada é socialmente injusta e economicamente ineficiente." (apud TAVARES; ASSIS, 1985, p. 82).

\section{DA ESTABILIZAÇÃO À ESTAGFLAÇÃO: A POLÍTICA ECONÔMICA DE FRANCO A ROUSSEFF (1992-2015)}

As consequências do desequilíbrio macroeconômico decorrente da opção adotada nos anos 1970 foram observadas durante a chamada "dé- 
cada perdida", entre os primeiros anos de 1980 até meados da década subsequente. A taxa de crescimento médio do PIB - de 11,1\% durante o "milagre econômico" e 7,1\% no II PND-, foi, em média, de 0,3\% negativa no lustro imediatamente posterior (1981-1985). Observou-se uma breve recuperação no período na segunda metade da dos anos 1980, quando a taxa de crescimento média ficou em $4,3 \%$, voltando a declinar, porém, para 1,3\% nos governos Collor e Franco (1990-1994).

A despeito dos índices supracitados não configurarem um cenário tecnicamente recessivo, a principal consequência da má gestão macroeconômica foi verificada na expressiva escalada do nível geral de preço. A inflação média, de acordo com o Índice Geral de Preços (IGP), que já era elevada na década de 1980, cresceu exponencialmente, alcançando $1.210 \%$ no período de 1990-1994.

Diante do cenário descrito e, principalmente, da frustração dos planos heterodoxos de estabilização adotados na década de 1980, o combate à hiperinflação tornara-se o principal desafio dos primeiros governos democraticamente eleitos após o regime autoritário (1964-1985). No que se refere especificamente aos efeitos deletérios sobre a renda, a inflação corroía mais fortemente o poder de compra da população de renda mais baixa, a qual não tinha acesso à proteção ofertada pela indexação de alguns ativos disponíveis no mercado financeiro. É nesse sentido que se pretende evidenciar a relevância do Plano Real não apenas para a estabilização monetária, como também para a reorganização econômica que permitiu o crescimento observado a partir de meados dos anos 2000.

\section{O Plano Real e suas principais consequências para a economia brasileira}

O diagnóstico da equipe econômica responsável pela formulação do Plano Real apontava para o desajuste nas contas públicas como a principal causa da inflação brasileira. Para os técnicos do governo Itamar Franco, tal problema sobrepujava a importância do componente inercial da inflação, leitura realizada pelos autores dos planos anteriores, os quais lançaram mão seguidas vezes do artifício do congelamento de preços.

Bacha (2012), por exemplo, destacava a existência de um "déficit potencial" nas contas públicas. De acordo com a sua interpretação, o déficit seria significativamente superior ao verificado no ano fiscal, uma

DADOS - Revista de Ciências Sociais, Rio de Janeiro, vol. 61, n 3, 2018 
Ivan Colangelo Salomão e Karlo Marques Junior

vez que existia um desajuste ex ante corroído pela inflação gerado na votação orçamentária, momento em que a previsão inflacionária era inferior à efetivamente verificada a posteriori.

Dessa forma, a primeira fase do Plano Real foi marcada pela tentativa de sanar o desajuste fiscal através do Programa de Ação Imediata (PAI) e da aprovação do Fundo Social de Emergência (FSE) - que posteriormente daria origem ao mecanismo da Desvinculação de Receitas da União (DRU). Ambos lograram resultados modestos, mas representaram a tendência de identificar a questão fiscal como uma das fontes do desequilíbrio macroeconômico brasileiro. Consequentemente, o déficit operacional ${ }^{11}$ de fato passou de $1,7 \%$ do PIB (1992) para $-1,1 \%$ (1994), enquanto o resultado primário foi de $1,6 \%$ para $5,2 \%$ nos respectivos anos.

Tão ou mais importante do que a própria execução das medidas contidas no plano - cuja segunda fase caracterizou-se pela adoção da nova moeda e pela consequente desindexação da economia brasileira -, foi a adoção de regras claras de política macroeconômicas a partir do segundo mandato de Cardoso (1999-2002).

Seguindo as proposições contidas no chamado "Novo Consenso Macroeconômico ${ }^{12 "}$ de cunho novo-keynesiano, abandonou-se o regime de metas cambiais assimétricas e adotou-se o assim designado "tripé macroeconômico", composto pelo regime de metas para a inflação, superávit primário e câmbio flutuante. Ademais, o desajuste fiscal foi combatido através da renegociação das dívidas estaduais, com a aprovação da Lei de Responsabilidade Fiscal (LRF), em 2000, e com a reforma parcial da Previdência Social.

A política monetária do Banco Central também sofreu inflexão quando este se propôs trazer a inflação para o centro da meta estipulada pelo Conselho Monetário Nacional (CMN), criando uma âncora nominal aos moldes da sugerida por Taylor (1993) e Bernanke et al. (1999). Tal mudança tinha por objetivo o balizamento das expectativas dos agentes econômicos, possibilitando um ambiente mais favorável às decisões de investimento. Deste modo, a inflação medida pelo Índice Nacional de Preços ao Consumidor Amplo (IPCA) manteve-se sob controle até 2002, com uma queda de quase 3 pontos percentuais em 2000 em relação ao ano anterior. O superávit primário, por sua vez, chegou a 3,9\% do PIB em 2002, depois de apresentar déficit no biênio 1996-1997. 
De milagres e espetáculos: o ciclo vicioso do eterno país do futuro

Como era de se esperar, o ajuste nas políticas macroeconômicas resultou em custo significativo no curto prazo. A variação do PIB sofreu uma desaceleração em relação ao já modesto crescimento médio de 2,6\% observado no período de 1995-1998, apresentando média de 2,1\% no quadriênio 1999-2002. A despeito da elevação do superávit primário, verificou-se um crescimento considerável da razão dívida líqui$\mathrm{da} / \mathrm{PIB}$, como consequência do aumento do custo da dívida provocado pela política monetária restritiva (SALOMÃO; MARQUES JUNIOR, 2016).

O ajuste macroeconômico pode ser considerado parcialmente responsável pelos resultados desfavoráveis em que incorreu a economia brasileira no primeiro momento. Tal ônus deve ser analisado, porém, como o ajustamento necessário à consolidação das bases que, junto a um cenário externo favorável nos primeiros anos do século XXI, sustentaram as altas taxas de crescimento do produto, com baixa inflação e redução da desigualdade.

Medo, esperança e espetáculo: a economia brasileira nos anos 2000

A despeito do temor gerado pela eleição de um candidato cujo partido manteve relação conflituosa com o empresariado desde a sua fundação, os dois mandatos do presidente Lula (2003-2010) foram caracterizados pela adoção de medidas que intensificaram o equilíbrio macroeconômico e reforçaram o ambiente de negócios, fortalecendo as reformas do governo anterior e azeitando o ambiente econômico-institucional ${ }^{13}$. Apoiado em uma vertiginosa melhoria dos termos de troca, observou-se uma taxa média de crescimento de $4 \%$ do PIB durante o período, não obstante os efeitos negativos da crise financeira internacional de 2008.

Em termos gerais, a política econômica de seu primeiro mandato (2003-2006) pode ser caracterizada pela manutenção, quando não ampliação, do já citado "tripé macroeconômico". Além disso, patrocinaram-se reformas estruturais importantes no referido período, dentre as quais destacam-se: (1) a da Previdência Social, com foco no regime do servidor público, a qual extinguiu a aposentadoria integral para os novos servidores públicos federais, que passaram a receber de acordo com a média da contribuição à previdência. A partir da reforma passou a ser cobrada uma contribuição de $11 \%$ dos servidores já aposentados e estabeleceu-se um limite máximo aos valores dos benefícios dos servi- 
Ivan Colangelo Salomão e Karlo Marques Junior

dores federais; (2) reformas microeconômicas em diversos campos, tais como regulamentação do crédito consignado, a nova Lei de Falência, instituição do patrimônio de afetação, bem como a implementação de instrumentos de apoio à inovação - como o Fundo Verde Amarelo, a Lei de Inovação e a Lei do Bem.

A adoção de tais medidas simpáticas ao mercado responde pelo ambiente de credibilidade que favoreceu a formação de expectativas positivas e possibilitaram a criação de uma âncora capaz de balizar as decisões de investimentos dos agentes econômicos. Pelo lado microeconômico, além da melhor regulamentação do ambiente de negócios, a redução de riscos de inadimplência também favoreceu o cenário como um todo. Com efeito, os resultados gerados pela política econômica austera dos primeiros anos do governo Lula foram reconhecidos pelo mercado internacional em 2008 através da outorga do investment grade por parte das agências internacionais de análise de risco.

A crise financeira iniciada em 2008 nos países centrais, contudo, afetou diretamente o desempenho da economia brasileira. Em 2009, após se observar uma trajetória de crescimento robusto desde 2004, o PIB encolheu $0,2 \%$, queda não verificada desde 1992 (-0,5\%). A reação inicial do governo se deu na forma de uma bem-sucedida política econômica anticíclica, cuja adoção imoderada, porém, veio a configurar a chamada “Nova Matriz Econômica" (doravante, NME).

Diversos indícios apontavam para os primeiros sinais de mudança de rumo quando da posse de Guido Mantega no Ministério da Fazenda em 2006. De acordo com Giambiagi (2011b), passou-se a verificar "a adoção de um discurso muito mais pró-consumo que pró-ajuste", o qual foi viabilizado por uma forte expansão do crédito e dos gastos públicos. Observou-se, dessa forma, uma taxa de crescimento do consumo superior à do PIB, resultado oposto ao praticado no período 2003-2006. Além disso, constatou-se um aumento de despesas primárias superior ao da receita, em oposição ao que se entregava desde a adoção do "tripé macroeconômico" em 1999. Tal expansão fiscal foi marcada principalmente pela intensificação das transferências diretas, como aposentadorias, aumentos reais do salário mínimo, benefícios assistenciais previstos na Lei Orgânica da Assistência Social (LOAS), expansão do seguro-desemprego, dentre outras.

A partir da eleição de Dilma Rousseff, em 2010, formou-se um ambiente político favorável à implementação e ao fortalecimento de políticas 
De milagres e espetáculos: o ciclo vicioso do eterno país do futuro

expansionistas e menos atentas às restrições intertemporais - isto é, restrições orçamentárias e inflacionárias a que economias de mercado estão inexoravelmente sujeitas. Segundo Pessôa (2013), "a ideia básica [da NME] era ajustar parâmetros macroeconômicos do Brasil que pareciam anômalos, como a taxa de juros reais muito alta e o câmbio muito valorizado". Além das políticas instrumentais de curto prazo, o autor aponta para uma tentativa de mudança estrutural da política econômica, passando a se priorizar "uma visão mais intervencionista e protecionista da política econômica e um realce do papel do Estado".

Com efeito, a economia brasileira atravessou relativamente bem o período mais problemático da crise internacional, apresentando uma forte recuperação econômica em 2010 e 2011 quando se observaram taxas de crescimento do PIB de 7,6\% e 3,9\%, respectivamente. O modelo de crescimento sustentado em políticas monetária, fiscal e creditícia expansionistas apresentou, no entanto, sinais de esgotamento tão logo se exauriu o limite fiscal comumente presente na história econômica do Brasil. De modo que, com exceção de 2013, quando a economia cresceu $3 \%$, os anos de 2012 e 2014 foram de baixo crescimento (1,9\% e 0,1\%, respectivamente), culminando na expressiva queda de 3,8\% em 2015. A inflação oficial aferida pelo IPCA em 2015 atingiu 10,7\% (a mais alta taxa desde 2002), quatro pontos percentuais acima do teto da meta.

Diante de tal cenário pessimista, a deterioração das expectativas dos agentes econômicos, principalmente empresários do setor industrial, manifestou-se da queda expressiva da formação bruta de capital fixo (FBCF), a qual retrocedeu 15\% no terceiro trimestre de 2015 em relação ao mesmo período do ano anterior, e 21,6\% se comparado ao mesmo período do ano de 2013.

Face às diversas críticas que responsabilizavam tal guinada na política econômica pela crise corrente, faz-se mister esquadrinhar algumas das principais medidas contidas na NME.

\section{Das políticas expansionistas à depressão: a economia brasileira na primeira metade dos anos 2010}

Os eixos sobre os quais repousou a Nova Matriz Econômica podem ser divididos em três paradigmas principais: (1) crença de ausência de restrições (sobretudo, orçamentárias); (2) ênfase na "vontade política" como guia infalível para a condução de ações de governo (ignorando aspectos básicos das negociações dentro de sistemas políticos comple- 
Ivan Colangelo Salomão e Karlo Marques Junior

xos); e (3) um solene desprezo pela inflação, mecanismo introdutor de sérias distorções nos cálculos dos agentes econômicos, usurpador do poder de compra das camadas menos favorecidas da sociedade e concentrador de renda. Ainda que por demais esquemática, pode-se analisar o conteúdo da NME do ponto de vista de sua instrumentalização em três vetores: políticas fiscal, monetária e creditícia, e intervencionismo imoderado.

\section{Política fiscal}

Observou-se expressiva redução do superávit primário do setor público, o qual se mantivera acima dos 3\% do PIB até o ano de 2009. Após uma leve redução em 2010 (2,1\%), voltou ao antigo patamar no ano subsequente. Foi a partir de 2012, contudo, que se verificou uma trajetória contínua de queda no indicador em relação ao PIB: - $0,57 \%$ (2014) e $-1,88 \%$ (2015).

Uma das principais rubricas responsáveis por tais resultados foi a dos subsídios, os quais saíram de um nível de 0,3\% em 2010 para significativos 1\% do PIB em 2014. O governo federal concedeu, apenas em 2014, $\mathrm{R} \$ 104$ bilhões em incentivos fiscais e desonerações tributárias ao setor produtivo, um aumento $\mathrm{R} \$ 26$ bilhões em relação ao ano anterior (PESSÔA, 2013).

A deterioração da situação fiscal conviveu, paralelamente, com a adoção de manobras pouco convencionais na contabilidade pública, as popularmente conhecidas "pedaladas fiscais". Tais medidas contribuíram ainda mais para a perda de credibilidade e o aumento da incerteza por parte dos agentes econômicos, afetando diretamente a confiança na qualidade da política fiscal praticada pelo governo.

De acordo com Barros e Afonso (2013), houve importantes alterações na política fiscal brasileira que se aprofundaram no primeiro governo Rousseff. Inicialmente, uma política expansionista semelhante ao que se observou em diversos países industrializados teve como objetivo amortecer, de forma anticíclica, os impactos da crise financeira. Contudo, tal estratégia foi exacerbada (a despeito do vertiginoso crescimento de 2010) a partir da adoção de uma série de medidas pouco usuais as quais visavam, principalmente, ao adiantamento de receitas e ao adiamento de despesas. 
De milagres e espetáculos: o ciclo vicioso do eterno país do futuro

Os autores relatam que embora medidas similares tenham sido adotadas em diferentes contextos no passado, inaugurou-se uma particularidade da política fiscal contra-cíclica brasileira jamais observada. Tratou-se da intensa concessão de crédito diretamente financiada com títulos públicos do Tesouro Nacional, intermediada, particularmente, pelo BNDES e, em menor escala, pela Caixa Econômica Federal. O volume de crédito fornecido por tais instituições financeiras era da ordem de 0,5\% do PIB em fevereiro de 2008; em junho de 2013, atingiu expressivos 9,6\% (BARROS; AFONSO, 2013).

Lança-se mão da hipótese de que, por trás de tais transações, havia uma "forma disfarçada de financiamento das contas públicas" à custa do endividamento do setor público. Isto ocorre porque tais bancos proviam receitas ao Tesouro por meio de dois mecanismos: (1) aquisição de ativos financeiros (ações de empresas públicas, principalmente da Petrobras, ou recebíveis e receitas futuras de outras empresas estatais); e (2) dividendos e tributos. Dessa maneira, o Tesouro Nacional teria encontrado um canal para transformar a emissão de títulos de dívida em receitas primárias, adiando o custo de tais medidas para um período subsequente, elevando a taxa de juros implícita e distanciando, assim, a dívida líquida do setor público de sua dívida bruta.

\section{Políticas monetária e creditícia}

A redução na meta da taxa SELIC - em uma conjuntura econômica em que a inflação medida pelo IPCA se encontrava acima do centro da meta - de 12,50\% a.a. (julho de 2007) para 7,25\% (outubro de 2012), repercutiu diretamente sobre inflação. O aumento generalizado dos preços observado a partir de meados de 2012 guarda expressiva correlação (negativa) com o voluntarismo da política monetária. A inflação medida pelo IPCA passou de 4,46\% (2007) para 6,50\% (2011) e atingiu, em 2015, 10,8\%, índice mais alto em 13 anos.

Conforme destaca Barbosa (2016), a análise da política monetária deve se basear na observação da relação entre a taxa de juros real praticada pela autoridade monetária e a taxa de juros natural da economia, definida pelo autor como a taxa que mantém a inflação no centro da meta e a economia em pleno emprego.

Assim, durante o período de 2003 a 2010, a política monetária mostrou-se contracionista e a taxa de juros real convergiu para a natural devido à queda da inflação. Neste caso, o BACEN alcançou os resulta-

DADOS - Revista de Ciências Sociais, Rio de Janeiro, vol. 61, nº 3, 2018 
dos previamente estipulados e manteve uma política crível. A partir da crise financeira de 2008, no entanto, a política monetária tornou-se expansionista, e a taxa de juros real recuou para valores abaixo da taxa natural. Entre meados de 2011 e o início de 2012, essa tendência de expansão da liquidez foi brevemente interrompida, para, na sequência, observar-se uma política fortemente expansionista a partir de 2013. Na visão de Barbosa (2016), o Banco Central não obedeceu ao protocolo do regime de metas para a inflação no período em questão, arcando, consequentemente, com a perda de credibilidade necessária para a condução da política monetária.

A política de crédito também foi marcada por uma forte expansão de recursos subsidiados pelo Tesouro Nacional e concedidos por bancos públicos. Além da pressão inflacionária, tal política impactou diretamente a dívida bruta do setor público (DBSP) além do considerável aumento da taxa de juros implícita da dívida líquida ${ }^{14}$. Dessa forma, a emissão de dívidas cotadas na taxa básica de juros para financiar ativos de baixa remuneração - como, por exemplo, a taxa de juros de longo prazo (TJLP) eleva a taxa implícita de juros da dívida líquida, sem que se verifique um significativo aumento da própria dívida líquida do setor público (DLSP) no curto prazo. Entretanto, tal medida se configurou em um "descolamento" da DBSP em relação à DLSP e, principalmente, no aumento dos custos financeiros do governo no longo prazo.

A respeito dos custos fiscais e do impacto da expansão creditícia fornecida principalmente pelo BNDES e subsidiado pelo Tesouro Nacional, faz-se relevante lembrar que parte do crédito emprestado pelo banco é captada no mercado de fundos emprestáveis por meio da emissão de dívida pública. O custo de captação desses recursos para o Tesouro Nacional supera a taxa cobrada pelo BNDES, elevando, assim, a dívida bruta do governo central e a taxa implícita de juros da dívida líquida.

Ao apresentarem dados que exemplificam essa ressalva, Araújo e De Negri (2017) destacam que o estoque de participação no funding do BNDES financiado pelo Tesouro correspondia a 0,5\% do PIB, em 2007, chegando a quase $10 \%$ em 2015 , o que equivale a um valor total de $\mathrm{R} \$$ 525 bilhões no período. O total de subsídios implícitos calculados pelo Tesouro Nacional atingiu aproximadamente $\mathrm{R} \$ 20$ bilhões apenas em 2015 , o que equivale aos gastos despendidos com o programa Bolsa Família. 
De milagres e espetáculos: o ciclo vicioso do eterno país do futuro

Os efeitos deletérios dessa medida sobre a condução da política econômica são conhecidos. Em primeiro lugar, o estímulo à demnnda agregada prnmovido pela política de crédito direcionado faz com que a taxa básica de juros se eleve para permitir que a meta de inflação seja alcançada. Além disso, uma vez que o financiamento de subsídios com recursos públicos eleva a dívida pública e aumenta a percepção de risco de default do governo, os investidores passam a demandar uma taxa mais elevada para financiar os déficits do setor público. $\mathrm{O}$ aumento do risco também exerce uma pressão de desvalorização da taxa de câmbio, a qual, por sua vez resulta em efeitos inflacionários a serem contidos, novamente, com uma taxa de juros ainda mais elevada. Finalmente, uma vez que parte da poupança agregada é alocada para financiar os investimentos subsidiados, a escassez de poupança no mercado de crédito eleva a taxa de juros de longo prazo no mercado livre de subsídios. Assim, crédito mais barato para os contemplados pela política pode se traduzir em crédito mais caro para as demais empresas e para as famílias. Esse mecanismo levou Loyola (2016) a argumentar que o Tesouro Nacional se tornou o "banco central do BNDES", uma vez que aquele fixa a taxa de juros para suas operações e exerce a função de emprestador de última instância.

Em suma, uma política ativa e pouco parcimoniosa de crédito subsidiado enfraquece os canais de transmissão da política monetária, exerce um efeito de alta na taxa SELIC e transfere custos financeiros dos que recebem subsídios para o restante da sociedade. Vale lembrar que se a inflação passa a responder mais fortemente à taxa SELIC, uma hipótese provável na ausência de elevados subsídios, o custo de desinflacionar a economia é menos elevado em termos de desemprego e renda - a chamada "taxa de sacrifício" a que o governo tem que necessariamente se submeter em um momento futuro.

\section{POLÍTICAS DE INTERVENÇÃO}

Durante o processo assim denominado pelo então ministro da Fazenda como "guerra cambial", adotou-se uma série de medidas protecionistas visando à defesa da competitividade da indústria acional. Na tentativa de evitar uma apreciação cambial, o governo alterou, entre 2008 e 2014, o Imposto sobre Operações Financeiras (IOF) mais de uma dezena de vezes ${ }^{15}$. Além disso, elevou, em 2012, a tarifa média de importação de $12 \%$ para $25 \%$ sobre 100 produtos, envolvendo os setores de si-

DADOS - Revista de Ciências Sociais, Rio de Janeiro, vol. 61, n 3, 2018 
derurgia, química, petroquímica, medicamentos, bens de capitais, entre outros.

Diversos foram os setores cujos funcionamentos sofreram interferência por parte do governo. Com o objetivo de controlar artificialmente a inflação, o mercado de combustíveis, por exemplo, foi diretamente afetado através do congelamento de preços praticado pela Petrobras. A ingerência causou redução significativa nos lucros da estatal e minou sua capacidade de investir devido ao alto endividamento e alavancagem a que teve que se submeter (PASTORE; PINOTTI, 2015).

Já no setor de energia elétrica, a redução do preço para as distribuidoras resultou em desarranjos microeconômicos onerosos. Na tentativa de reduzir as tarifas ao consumidor final em até $20 \%$, o governo desembolsou, em 2012, aproximadamente $\mathrm{R} \$ 26$ bilhões - entre empréstimos e indenização para empresas de geração e transmissão - por contratos com vencimentos entre 2015 e 2017, apenas.

A esse respeito, o relatório anual do Tribunal de Contas da União (TCU) de 2014 atestou que as medidas "trouxeram desequilíbrios nas contas do setor elétrico, dificultando o contrato de distribuidoras com geradoras de energia." Nesse sentido, o documento calculava que "se as distribuidoras estão em desequilíbrio financeiro, as geradoras que não aderiram à renovação antecipada das concessões tiveram ganhos superiores a 700\% no mercado de curto prazo." (TRIBUNAL DE CONTAS DA UNIÃO, 2015, p. 56).

O intervencionismo também ganhou forma através da política de conteúdo nacional, que consistiu em uma imposição à Petrobras de uma cota mínima de insumos nacionais nas atividades de exploração de petróleo e gás, bem como na tentativa de impulsionar a indústria naval, gerando diminuição da produtividade dos referidos setores. Como sugerem Barbosa e Pessôa (2015), tal política desprezava o custo de oportunidade dos recursos sociais, incorrendo em ineficiência na alocação dos mesmos e prejuízo não apenas para as empresas afetadas, mas para toda sociedade brasileira compelida a pagar tarifas mais elevadas.

Condizente com o novo elemento a ser agregado à fórmula "Campos Sales-Rodrigues Alves", conforme sugere este trabalho, o ajuste macroeconômico realizado a partir de 2015 com a nomeação de Joaquim Levy para o Ministério da Fazenda, e em especial, após a ascensão de Michel Temer à Presidência da República, vai ao encontro da hipótese 
aqui levantada. A funcionalidade de suas medidas, porém, só poderá ser mais bem analisada com o benefício do transcorrer cronológico da história.

\section{A questão da desindustrialização}

Muito embora as origens da desindustrialização remontem a épocas anteriores à NME, o aprofundamento de suas consequências observado durante os anos 2000 deslinda a contraprodutividade da política que, ironicamente, visava à defesa do setor industrial.

De acordo com Rowthorn e Ramaswany (1999), a desindustrialização pode ser causada por fatores internos e externos. Dentre os primeiros, mais comuns aos países desenvolvidos, destaca-se a mudança na relação entre a elasticidade renda da demanda por produtos manufaturados e serviços. Dado que a segunda cresce mais rapidamente que a primeira, o próprio desenvolvimento econômico acarreta um aumento da participação do setor terciário no PIB.

Sabe-se, ainda, que o aumento da produtividade da indústria é superior ao de outros setores, de modo que, conforme uma economia se industrializa, observa-se uma realocação da mão de obra para outros setores, notadamente o de serviços. Espera-se, assim, que a participação relativa do emprego industrial tenda a diminuir naturalmente à medida que se eleva a renda per capita, uma vez que a própria estrutura produtiva passa a expandir, modernizar e diversificar o setor de serviços. Eis o caso da "desindustrialização positiva", processo pelo qual passou a maioria dos países desenvolvidos.

No que se refere aos fatores externos, o surgimento das chamadas cadeias globais de produção contribuiu para a queda relativa da participação do setor industrial no PIB ao ensejar a exportação de plantas fabris para países que dispõem de vantagens comparativas relacionadas ao trabalho ou a recursos naturais. Como resultado, algumas economias desenvolvidas acabaram por se especializar em setores de serviços de alto valor agregado, como os Estados Unidos e a Inglaterra.

Por fim, trata-se da "doença holandesa" a causa mais comumente aludida. Cunhou-se tal expressão para designar a perda da competitividade da indústria nacional

advinda da apreciação cambial, a qual resulta, por sua vez, da abundância relativa de determinado recurso natural ${ }^{16}$. Sua principal conse- 
quência reside na especialização ricardiana associada à "reprimarização" da pauta de exportações ou à produção de bens industriais intensivos em trabalho, resultando em constantes déficits comerciais da indústria e superávits comerciais nos outros setores. Reconhecida como uma "desindustrialização negativa ou precoce" - uma vez que o processo se inicia antes que se atinja determinado nível de renda per capita-, as economias que padecem de valorização cambial indevida não esgotam todas as possibilidades de desenvolvimento decorrentes do processo de industrialização.

A participação do setor industrial no PIB brasileiro alcançou seu ápice em meados dos anos 1970, quando o amadurecimento das inversões contidas no II PND completou a estrutura do parque industrial brasileiro. Autores como Arend (2009) e Bresser-Pereira (2013) apontam para o início da desindustrialização ainda na década de 1980, quando a crise da dívida externa impôs uma agenda recessiva aos países em desenvolvimento que resultou não apenas na contração da demanda agregada, mas principalmente no fim do ciclo de investimentos na indústria. Já nos anos 1990, a abertura comercial e financeira passou a atuar a favor da apreciação cambial, elevando o salário real, incitando o consumo (de produtos importados, inclusive) e desincentivando o investimento produtivo.

O diagnóstico torna-se mais preciso quando analisados os dados referentes aos anos 2000. Diversos são os analistas que ressaltam o recrudescimento do fenômeno após a mudança da política cambial (em janeiro de 1999). Bresser-Pereira e Marconi (2008) e Bresser-Pereira e Gala (2010), por exemplo, argumentam que a paulatina valorização cambial observada a partir da metade daquela década reverteu o incentivo fugaz alcançado com a depreciação do real ocorrida a partir de 2002.

Ainda que de forma nuançada, economistas ortodoxos também ratificam tal entendimento. Para Bacha (2013), por exemplo, a queda da participação da indústria de transformação entre 2005 e 2011 (de 18\% para $16 \%$ ) pode ser delegada, em grande medida, à bonança externa de que o país desfrutou no período. Bacha e Fishlow (2012), por sua vez, demonstram que o expressivo aumento dos preços das commodities no mercado internacional observado naquele momento contribuiu decisivamente para que o setor industrial perdesse participação em diversas economias latino-americanas. 
De milagres e espetáculos: o ciclo vicioso do eterno país do futuro

Por outro lado, há autores que, embora reconheçam a queda constante da participação da indústria no PIB brasileiro, analisam esse fenômeno sob outros aspectos. Além de eximirem algumas das justificativas geralmente levantadas pelos economistas desenvolvimentistas, também procuram atenuar os efeitos deletérios desse processo.

De acordo com Nassif (2008), os dados de que se dispõe não autorizam o diagnóstico preciso no que concerne à desindustrialização no Brasil. Sua argumentação repousa sobre o fato de que não se "assistiu a um processo generalizado de mudança na realocação de recursos produtivos e no padrão de especialização dos setores com tecnologias intensivas em escala, diferenciada e science-based para as indústrias baseadas em recursos naturais e em trabalho." (p. 89).

Sob o mesmo prisma, com viés sensivelmente distinto, no entanto, Bonelli e Pessôa (2010) aceitam o recuo do setor manufatureiro na composição do PIB, questionando, porém, a inevitabilidade do processo. Para tais autores, a "suposta desindustrialização" teria sido causada, de fato, pela valorização do câmbio em determinados momentos. Além disso, o avanço da indústria chinesa nos mercados internacionais - impulsionado por soldos diminutos e pela desvalorização do yuan - representa uma ameaça incontornável a todas as economias do globo.

Os autores sustentam, porém, que não há em curso um "processo avassalador" de desindustrialização, "mas, apenas, indícios a partir da experiência histórica de mais longo prazo." Ademais, atestam que a indústria brasileira tem apresentado desempenho "bastante satisfatório", pois não apenas acompanha a trajetória do PIB, como demonstra "vigor" em determinadas épocas de recuperação da atividade econômica.

\section{ASPECTOS TEÓRICOS DO CICLO VICIOSO DA ECONOMIA BRASILEIRA CONTEMPORÂNEA: CICLO POPULISTA E INCONSISTÊNCIA TEMPORAL}

As repercussões negativas da tentativa de se estimular o crescimento econômico através da intervenção estatal e de mecanismos expansionistas de curto-prazo já estão consagradas na literatura especializada. Ademais, as próprias evidências empíricas granjeiam um quase consenso entre os autores quanto ao ônus inevitável de seus resultados.

DADOS - Revista de Ciências Sociais, Rio de Janeiro, vol. 61, n 3, 2018 


\section{O ciclo populista}

Um primeiro approach teórico que contribui para o melhor entendimento do fenômeno brasileiro diz respeito ao conceito de populismo econômico, o qual encontra na definição de Dornbusch e Edwards (1991) sua concepção mais propalada. Para os autores, trata-se de uma política econômica que enfatiza o crescimento econômico e a distribuição de renda, ignora os riscos de inflação e déficit fiscal, estrangulamento externo e a reação dos agentes econômicos a políticas agressivas contrárias ao mercado. No mesmo sentido, Bresser-Pereira (1991) o identifica como um fenômeno "baseado em um distributivismo ingênuo e em um desenvolvimentismo que não mede custos. Desenvolvimento econômico e distribuição de renda são entendidos como dois objetivos que podem ser alcançados com relativa facilidade pelo, de um lado, aumento dos investimentos e dos gastos sociais do Estado, e, de outro, pelo aumento de salários".

De acordo com Dornbusch e Edwards, o populismo econômico caracteriza-se pela ocorrência de quatro fases. Na primeira, o governo adota políticas que promovem crescimento expressivo do produto, salários reais e nível de emprego. A expansão da demanda é compensada pela redução de estoques e aumento das importações, o que atenua as pressões inflacionárias. O financiamento das importações pode se dar por redução das reservas cambiais ou suspensão dos pagamentos ao exterior. A segunda fase destaca-se por gargalos na oferta. Com os estoques reduzidos, faz-se necessário um realinhamento de preços, controle cambial, e de algum tipo de medida protecionista. Como consequência, a inflação aumenta, ainda que os salários permaneçam elevados. $\mathrm{Na}$ terceira fase, tais desequilíbrios entre oferta e demanda, aliados à crise cambial, ensejam a fuga de capitais e a desmonetização da economia, reforçando o déficit público e a queda dos salários reais. Na última etapa, já sob um novo governo, torna-se imperiosa a adoção de políticas ortodoxas de estabilização.

Conquanto se foque em outro conceito - a credibilidade--, o modelo de Barro (1986) também contribui para problematizar, do ponto de vista teórico, a política econômica dos períodos em análise. Partindo de um arcabouço conhecido como "jogos de política", o autor identifica a recorrência de três fases na condução da política econômica. Na primeira, adotam-se medidas ortodoxas de estabilização. Diante das perdas inerentes a um período de austeridade, os agentes econômicos reagem 
De milagres e espetáculos: o ciclo vicioso do eterno país do futuro

e aferem a força do governo, testando a capacidade deste de seguir a política inicialmente executada: se do tipo "forte", o governo resiste às pressões; se "fraco", cede, passando gradualmente para a segunda fase, de "randomização". Nesta, o governo, desencontrado, adotaria políticas oscilantes, geralmente contraditórias a favor e contra a

estabilidade. Torna-se comum os policymakers cederem a coações em determinadas áreas e compensá-las em outra: por exemplo, abranda-se a política monetária e, a seguir, empenha-se uma política fiscal contracionista. Por fim, ao perceber a ambivalência dessa postura, e diante do acirramento da crise política, o governo sucumbe e adentra a terceira fase, abandonando por completo a opção pela estabilidade ao adotar políticas claramente expansionistas, tal qual o governo populista de Dornbusch e Edwards.

Diversos outros autores também se dispuseram a analisar o fenômeno do populismo sob a ótica econômica, como, por exemplo, DíazAlejandro (1991) e Sachs (1991). A despeito de nuances entre os distintos diagnósticos, depreende-se dos respectivos modelos determinadas medidas que parecem compor seu "núcleo duro": (1) expansão imoderada dos gastos públicos; (2) apreciação da taxa de câmbio; (3) aumento salarial acima da produtividade.

De forma sumarizada, constata-se que a política econômica populista privilegia o crescimento irresponsável de curto prazo associado à rejeição a políticas de estabilização, desconsiderando a existência de restrições econômicas. Nesse sentido, tornar-se-ia insustentável do ponto de vista dinâmico, pois a artificialidade fugaz da expansão inicial do produto apenas postergaria o ônus a ser colhido futuramente, delegando à sociedade o preço da imprudência do policymaker populista.

É possível que as especificidades de cada caso imponham restrições para se enquadrar hermeticamente os governos militares e de Rousseff em tais conceituações do populismo. Contudo, as conformidades entre o modelo teórico e as evidências empíricas

- principalmente no que toca à expansão do gasto público e à faculdade intervencionista atribuída ao ente estatal - contribuem, ainda que marginalmente, para uma caracterização mais bem definida dos respectivos períodos.

A inconsistência intertemporal da política econômica Kydland e Prescott (1977) discorrem acerca da inconsistência dinâmica da políti-

DADOS - Revista de Ciências Sociais, Rio de Janeiro, vol. 61, n 3, 2018 
Ivan Colangelo Salomão e Karlo Marques Junior

ca econômica, conceito que incitou um amplo debate sobre a necessidade de regras que limitem o espaço para voluntarismos por parte dos formuladores de política econômica.

Segundo os autores, há uma política ótima para um determinado período em termos de crescimento econômico. Se a mesma implicar inflação, déficit público e instabilidade macroeconômica em momentos subsequentes, deve ser considerada dinamicamente inconsistente. Se, na tentativa de maximizar a renda agregada, a política

resultar em inflação e no descumprimento da restrição orçamentária intertemporal do governo - isto é, se o governo não consegue honrar seus compromissos fiscais em períodos subsequentes - também deve ser classificada como tal. Nesta visão, os policymakers não são capazes de explorar de modo permanente o trade-off entre inflação e desemprego.

Neste caso, uma política que busque uma taxa de crescimento do produto para além do seu potencial em um determinado período incorrerá, ulteriormente, em déficits fiscais e/ou em aumentos inflacionários, e o produto da economia voltará para seu nível potencial. A persistência do déficit e da inflação poderá, inclusive, reduzir o produto potencial e sua taxa de crescimento (não o maximizando intertemporalmente, isto é, ao longo do tempo). Esse tipo de política é justificado pelo chamado "viés inflacionário" da política econômica.

Diante das considerações tecidas acima, a política econômica mais adequada seria aquela que assegurasse a estabilidade dos preços e o cumprimento da restrição orçamentária intertemporal do governo. Isto é, em um ambiente no qual os agentes racionais alteram suas expectativas a cada mudança nos parâmetros da política econômica, o bem-estar social será maximizado quando forem adotadas políticas com regras claras que primem pela estabilidade das variáveis macroeconômicas e que permitam aos agentes alocarem seus recursos da maneira mais eficiente possível.

A partir desse mesmo arcabouço teórico, Romer (2012) chama a atenção para a explosão inflacionária observada em determinados países industrializados durante os anos 1970 como decorrência do rápido crescimento no estoque de moeda em circulação. O autor sugere que o "viés inflacionário", criado pelo trade-off de curto prazo entre produto e inflação, desincentiva o governo a comprometer-se com uma política de austeridade. Dessa forma, criar-se-ia um ciclo vicioso em que se a 
inflação esperada é baixa, o custo marginal de uma política inflacionária pode ser irrisório, motivando políticas expansionistas. Contudo, tais políticas incorrem, no longo prazo, em desequilíbrios econômicos, tais como inflação e baixo crescimento.

Para Bernanke et al. (1999), regras de políticas macroeconômicas atuam como uma âncora nominal que baliza as expectativas dos agentes a respeito da formação de preços. Considerando o controle inflacionário como pré-condição para o crescimento sustentável, os autores defendem o regime de metas para a inflação como a instituição ideal para ancorar e balizar as expectativas dos agentes econômicos em relação à dinâmica dos preços. A volatilidade inflacionária decorrente da ausência desse mecanismo compromete não apenas a tomada de decisões de consumo por parte das famílias, mas principalmente as decisões de investimento por parte das firmas.

Além disso, um regime de regras críveis em relação à política monetária também reforçaria a construção de um ambiente institucional que mantenha o Banco Central menos exposto a um viés inflacionário. Isso ocorre devido à possibilidade de imunizá-lo quanto à adoção de uma política dinamicamente inconsistente, garantindo-lhe maior autonomia operacional com vistas à estabilidade da moeda. Essa precaução é especialmente relevante nas economias emergentes, as quais, segundo Mishkin (2000), devem superar a reputação histórica de má administração da política monetária.

Com efeito, a política econômica brasileira sofre de um forte viés inflacionário causado por uma gama de motivos de cunho político. De forma geral, esse fenômeno é reforçado quando o policymaker, utilizando-se de políticas discricionárias, cria inflação surpresa a fim de levar o nível de emprego para o maior nível possível, mas que possui o custo de acelerar a inflação ${ }^{17}$. Os supostos efeitos positivos dessa estratégia sobre o nível de emprego são neutralizados quando os agentes percebem a intenção dela.

É importante ressaltar que há um determinado consenso entre diversos analistas ${ }^{18}$ de que este viés pode ser neutralizado - em maior ou menor grau - por mecanismos institucionais que mitiguem a discricionariedade da atuação dos formuladores de política econômica, tais como a adoção de regras para as políticas econômicas, cooperação entre política monetária e fiscal e concessão de autonomia para a atuação do Banco Central, entre outras. 


\section{CONSIDERAÇÕES FINAIS}

Muito embora já tenha se manifestado pontualmente em análises jornalísticas, o cotejamento histórico aqui apresentado não foi suficientemente explorado pela literatura acadêmica em virtude da contemporaneidade dos fatos. Buscou-se neste trabalho adicionar novos elementos, os quais sugerem que a adoção de políticas econômicas intervencionistas que privilegiem o crescimento de curto prazo não se sustenta do ponto de vista intertemporal. Argumentou-se, ainda, que dois dos principais momentos de crescimento acelerado por que passou recentemente a economia brasileira deveram-se mais às medidas de equilíbrio fiscal e monetário adotadas anteriormente do que à condução expansionista da política instrumental propriamente dita.

Os fatos históricos relatados e o referencial teórico utilizado dão suporte à sequência que resume a hipótese central do texto: ajustes fiscais e monetários permitem a expansão econômica, que se torna excessiva por estímulos expansionistas advindos dos ciclos populistas, os quais, por sua vez, geram desequilíbrios e a necessidade de novo ajuste.

Não se pode minimizar, porém, o mérito daqueles que operaram os respectivos casos, com alguma licenciosidade, de "sucesso". Refutar as conquistas obtidas durante o período do "milagre" - mormente as da classe média - ou os avanços sociais alcançados no decorrer dos anos 2000 é depor contra fatos históricos. O que se deve almejar, contudo, é a certeza de que o desenvolvimento extrapola o simples manejo curtoprazista dos instrumentos de política econômica. Crescimento sustentado requer maturidade, ousadia e, principalmente, sacrifícios.

É nesse sentido que se deve atentar para uma questão ainda mais relevante: as reformas estruturais exigidas pela realidade brasileira. O nó fiscal que permeia os demais problemas econômicos do país não se deve apenas à condução temerária dos dispêndios públicos e da arrecadação federal nos últimos anos. Sabe-se que a estrutura de tais gastos, muitas vezes atrelados a regras não condizentes com um país de renda média, atenta de forma fulcral contra a sustentabilidade das contas públicas.

Nesse contexto, o equacionamento dos problemas fiscais, especialmente a disfuncionalidade da Previdência Social faz-se particularmente relevante. Outra rubrica de grande impacto no orçamento federal, o serviço da dívida pública, também poderia ser otimizada se a 
mesma fosse submetida a uma auditoria responsável. Pelo lado da arrecadação, uma política tributária que se baseasse em uma lógica direta e progressiva atuaria diretamente no sentido do equilíbrio fiscal. Raro consenso entre os analistas, a atual estrutura tributária brasileira depõe decisivamente contra a estabilidade fiscal. Primeiro, porque sabidamente injusta; segundo, porque comprovadamente ineficiente. Dada a elevada propensão marginal a consumir da população de menor poder aquisitivo, um pequeno incentivo fiscal (via redução de impostos indiretos, por exemplo) atuaria de modo muito mais eficaz quando da necessidade de se estimular a demanda agregada. Não se defende, desse modo, o aumento da carga tributária; antes, a sua redução, desde que aliada a um premente reequilíbrio.

Ainda que a "macroeconomia do homem cordial", conforme a oportuna expressão cunhada por Abreu (1994), tenha fincado raízes nos corações e mentes de vasta parcela da população brasileira, deve-se enaltecer os benefícios perenes do desenvolvimento institucional, o qual não se limita, como se sabe, à esfera da condução cotidiana da política econômica.Enquanto não se estabelecerem instituições que garantam clareza e estabilidade na administração da coisa pública, o país dependerá de personagens efêmeros para sua improvável redenção.

Recebido para publicação em 30 de março de 2016

Reapresentado em 18 de março de 2018

Aprovado para publicação em 30 de julho de 2018 
Ivan Colangelo Salomão e Karlo Marques Junior

\section{NOTAS}

1. Conforme explicam Fonseca e Monteiro (2005), a fórmula "sugeria que primeiro dever-se-ia passar por uma etapa de saneamento, com prioridade à busca de equilíbrio orçamentário, mesmo em prejuízo ao crescimento econômico (o que lembrava a política ortodoxa de Campos Sales) para, após conseguida a estabilidade, ingressar-se numa fase de crescimento (Rodrigues Alves)."

2. Pela nova metodologia, acrescia-se ao salário real médio verificado no biênio anterior a porcentagem correspondente ao aumento da produtividade no mesmo período, valor, este estipulado pelo governo.

3. Do ponto de vista do financiamento das atividades públicas, a reforma criou um mercado de dívida pública ao instituir as obrigações reajustáveis do Tesouro Nacional (ORTN).

4. Questionado sobre quais teriam sido as causas do "milagre", o próprio ministro Delfim Netto (2014) rechaçou a aura mágica imputada à sua gestão: "Nunca houve milagre. Milagre é efeito sem causa. O crescimento do Brasil naquele período foi consequência do trabalho dos brasileiros, basicamente da grande arrumação que houve no setor econômico, produzido no governo Castelo Branco."

5. Calcula-se que, ao final do regime militar, o governo tenha criado aproximadamente 231 novas empresas estatais.

6. O excesso de liquidez observado naquele período deveu-se, em um primeiro momento, aos robustos déficits do balanço de pagamentos em que incorriam a economia norte-americana, resultando na criação do chamado mercado dos "eurodólares". Tais recursos eram investidos em bancos americanos sediados na Europa, os quais buscavam fugir do rígido controle da autoridade monetária dos Estados Unidos.

7. Campos (1998) testemunhou o debate travado internamente entre Mario Henrique Simonsen e os desenvolvimentistas da equipe econômica, sobretudo o ministro do Planejamento, João Paulo dos Reis Velloso. Segundo o autor, Simonsen acreditava que o governo subjugava a severidade da crise, defendendo, portanto, "contenção e austeridade". De acordo com Gaspari (2004), quando questionado acerca da plausibilidade das medidas contidas no II PND, Simonsen teria respondido: "não leio ficção".

8. Na opinião de um dos principais atores do regime militar, o ex-ministro Delfim Netto (2014), a opção pelo ajustamento pelo lado da oferta custou caro à economia brasileira: "Quem quebrou o Brasil foi o Geisel."

9. Em seu discurso de posse, Delfim Netto tentou ratificar-em vão, como viria a provar a história - a aura mística que sobre ele pairava ao anunciar a adoção de uma nova matriz econômica: "Senhores, preparem seus arados e suas máquinas: nós vamos crescer." (apud CRUZ, 1982, p. 69).

10. Bacha (1982) estimou que a decisão de não recorrer ao suporte do FMI, já no final de 1980, pode ter custado ao país cerca de 400 milhões de dólares em reservas internacionais.

11. Segundo Zini Junior (1991, p. 105), o déficit operacional refere-se ao déficit nominal diminuído da correção monetária e cambial. Ou seja, é a "necessidade de financia- 
De milagres e espetáculos: o ciclo vicioso do eterno país do futuro

mento do setor público, excluindo-se os efeitos da correção monetária e cambial nas despesas e nas receitas." (EUZÉBIO, 2009).

12. Emprega-se o referido conceito no sentido oferecido por Licha (2015, p. 82).

13. Conforme arrola Giambiagi (2011b), as primeiras medidas de política econômica adotadas pelo novo governo foram: nomeação do ex-presidente mundial do Bank Boston, Henrique Meirelles, para comandar o Banco Central; elevação da taxa nominal de juros SELIC de $25 \%$ para $26,5 \%$ a.a. em fevereiro de 2003; anúncio das metas de inflação de 8,5\% e 5,5\% para os dois anos sucessivos; e elevação da meta de superávit primário de $3,75 \%$ para $4,25 \%$ do PIB para todo o primeiro mandato.

14. A definição mais comezinha de taxa de juros implícita da dívida líquida consiste na diferença dos juros pagos pelos passivos do setor público e os recebidos pelos ativos, em grande parte constituídos pelas reservas cambiais e pelos créditos concedidos pelo BNDES ao setor privado.

15. A tentativa de desvalorização da taxa de câmbio através das operações com swaps cambiais renderem um prejuízo de aproximadamente $\mathrm{R} \$ 120$ bilhões ao Banco Central até o final de setembro de 2015.

16. O conceito de doença holandesa foi posteriormente ampliado a fim de abarcar uma segunda causa. A abundância relativa de recursos humanos também poderia resultar na valorização excessiva da taxa de câmbio real uma vez que levaria a economia a se especializar na produção de tradables manufaturados intensivos em mão de obra.

17. Cukierman e Gerlach (2003) cunharam este fenômeno com o termo "viés KPBG" em alusão às duas duplas de economistas que se dedicaram ao tema, Kydland-Prescott e Barro-Gordon.

18. Dentre os quais, pode-se citar Barro e Gordon (1983), Alesina (1987), Cukierman (1992), Alesina e Summers (1993) e Alesina e Gatti (1995). 
Ivan Colangelo Salomão e Karlo Marques Junior

\section{REFERÊNCIAS BIBLIOGRÁFICAS}

ABREU, Marcelo de P. Crescimento rápido e limites do modelo autárquico. In: LAMOUNIER, Bolivar; CARNEIRO, Dionísio D.; ABREU, Marcelo de P. (Orgs.). 50Anos de Brasil: 50 Anos de Fundação Getulio Vargas. Rio de Janeiro: Editora FGV,1994.

ALESINA, Alberto. Macroeconomic policy in a two-party system as a repeated game. The Quarterly Journal of Economics, p. 651-678, 1987.

ALESINA, Alberto; GATTI, Roberta. Independent central banks: low inflation at no cost? The American Economic Review, v. 85, n. 2, p. 196-200, 1995.

ALESINA, Alberto; SUMMERS, Lawrence H. Central bank independence and macroeconomic performance: some comparative evidence. Journal of Money, Creditand Banking, v. 25, n. 2, p. 151-162, 1993.

ARAÚJO, Bruno César; DE NEGRI, João Alberto. O Tamanho do BNDES e resposta à crise: uma comparação internacional. Radar, n. 51. Brasília: IPEA, 2017.

AREND, Marcelo. 50 anos de industrialização do Brasil (1955-2005): uma análise evolucionária. Tese (Doutorado em Economia). Universidade Federal do Rio Grande do Sul, Faculdade de Ciências Econômicas, Programa de Pós-Graduação em Economia, Porto Alegre, 2009.

BACHA, Edmar L. Por uma política econômica positiva. In: ARIDA, Persio (Org.). Dívida externa, recessão e ajuste estrutural: o Brasil diante da crise. Rio de janeiro: Paze Terra, 1982.

. Belíndia 2.0. Fábulas e ensaios sobre o país dos contrastes. Civilização Brasileira, 2012.

. Bonança externa e desindustrialização no Brasil: uma análise do período 2005-2011. In: BACHA, Edmar; BOLLE, Monica B. de (orgs.). O futuro da indústria no Brasil. Desindustrialização em debate. Rio de Janeiro: Civilização Brasileira, 2013.

BACHA, Edmar L.; FISHLOW, Albert. Recent commodity price boom and Latin American Growth: more than New Bottles for an Old Wine? The Oxford LatinAmerican Economics Handbook, p. 394-410, 2012.

BARBOSA, Fernando H.; PESSÔA, Samuel de A. Desaceleração recente da economia. In: Sob a Luz do Sol: uma agenda para o Brasil. Centro de Debates de Políticas Públicas, 2015.

BARBOSA, Fernando H. A Política Monetária do PT. Conjuntura Econômica. Rio de Janeiro: Editora FGV, 2016

BARRO, Robert. Reputation in a Model of Monetary Policy with Incomplete Information. Journal of Monetary Economics, 17(1), p. 3-20, 1986.

BARROS, Gabriel L.; AFONSO, José R. Uma política fiscal atípica. In: BONELLI, Regis; CASTELAR PINHEIRO, Armando. (Orgs.). Ensaios IBRE de economiabrasileira. Rio de Janeiro: Editora FGV, 2013.

BARRO, Robert J.; GORDON, David B. Rules, discretion and reputation in a model of monetary policy. Journal of Monetary Economics, v. 12, n. 1, p. 101-121, 1983. 
BERNANKE, Ben S.; LAUBACH, Thomas; MISHKIN, Frederic S.; POSEN, Adam S. Inflation Targeting: Lessons from the International Experience. Princeton: PrincetonUniversity Press, 1999.

BONELLI, Regis; PESSÔA, Samuel de A. A desindustrialização brasileira em debate. Carta do IBRE. Rio de Janeiro: FGV, 2010.

BRESSER-PEREIRA,LuizCarlos.PopulismoEconômico:Ortodoxia, Desenvolvimentismo e Populismo na América Latina. São Paulo: Nobel, 1991.

. Prefácio. In: AZEVEDO, André Filipe Z. de; FEIJÓ, Carmem; CORONEL, Daniel A. (Orgs.). A desindustrialização brasileira. São Leopoldo: Editora Unisinos, 2013.

BRESSER-PEREIRA, Luiz Carlos; GALA, Paulo A. Macroeconomia estruturalista do desenvolvimento e novo-desenvolvimentismo. Santiago, Revista de la Cepal, n. 100, 2010.

BRESSER-PEREIRA, Luiz Carlos; MARCONI, Nelson. Existe doença holandesa no Brasil? Anais do IV Fórum de Economia de São Paulo, Fundação Getúlio Vargas. São Paulo: FGV, 2008.

CAMPOS, Roberto de O. Mario Simonsen, um matemático humanista. RevistaBrasileira de Economia, Edição Especial, 1998.

CARNEIRO, Dionísio D. Crise e esperança. In: ABREU, Marcelo de P. (Org.). Aordem do progresso. Cem anos de política econômica republicana. Rio de Janeiro:Campus, 1992.

CASTRO, Antonio B. de. Ajustamento x transformação. A economia brasileira de 1974 a 1984. In: CASTRO, Antonio B. de; SOUZA, Francisco P. A economia brasileira emmarcha forçada. São Paulo: Paz e Terra, 1985.

CASTRO, Lavínia B. Privatização, Abertura e Desindexação: a Primeira Metade dos anos 90 (1990-1994).In: GIAMBIAGI, Fabioet al. (org.). Economia Brasileira Contemporânea. Rio de Janeiro: Campus-Elsevier, 2011.

CRUZ, Paulo D. C. Notas sobre o endividamento externo brasileiro nos anos setenta. In: BELLUZZO, Luiz Gonzaga de M.; COUTINHO, Renata. Desenvolvimento capitalistano Brasil: ensaios sobre a crise. São Paulo: Brasiliense, 1982.

CUKIERMAN, Alex. Central bank strategy, credibility, and independence: Theory and evidence. Cambridge: MIT press, 1992.

CUKIERMAN, Alex; GERLACH, Stefan. The inflation bias revisited: Theory and some international evidence. The Manchester School, v. 71, n. 5, p. 541-565, 2003.

DELFIM NETTO, Antonio. Entrevista. Folha de São Paulo. Acesso em 15 de março de 2016. Disponível em: http://www1.folha.uol.com.br/poder/2014/04/1436007-quemquebrou-o-brasil-foi-o-geisel-aforma-delfim.shtml

DIAZ-ALEJANDRO, Carlos F. Southern Cone Stabilization Programs. In: CLINE, W.; WEINTRAUB, S. (ed.). Economic Stabilization in Developing Countries. Washington, D.C.: The Brooking Institution, 1991.

DORNBUSCH, Rudiger; EDWARDS, Sebastian. The Macroeconomics of Populism inLatin America. Chicago: The University of Chicago Press, 1991.

DADOS - Revista de Ciências Sociais, Rio de Janeiro, vol. 61, n 3, 2018 


\section{Ivan Colangelo Salomão e Karlo Marques Junior}

EUZÉBIO. Gi son LuiE, Quest,S do Desenvolvimento - Os vários tipos de déficit. Desafios do Desenvolvimento, Brasília: IPEA, Ano 6, Edição 50, 2009.

FONSECA, Pedro Cezar D. Legitimidade e credibilidade: impasses da política econômica do governo Goulart. Estudos Econômicos, São Paulo, v. 34, n. 3, p. 587-622, jul./set. 2004.

FONSECA, Pedro Cezar. D.; MONTEIRO, Sérgio M. M. Credibilidade e populismo: a política econômica dos governos Vargas e Goulart. Revista Brasileira de Economia, Rio de Janeiro, v. 59, n. 2, abr./jun. 2005.

GASPARI, Elio. A Ditadura Encurralada. São Paulo: Companhia da Letras, 2004.

GIAMBIAGI, Fabio. Estabilização, Reformas e Desequilíbrios Macroeconômicos: Os Anos FHC (1995-2002). In: GIAMBIAGI, Fabio et al. (Orgs.). Economia Brasileira Contemporânea. Rio de Janeiro: Campus-Elsevier, 2011a.

ـ Rompendo com a Ruptura: o governo Lula (2003-2010). In: GIAMBIAGI, Fabio et al. (Orgs.). Economia Brasileira Contemporânea. Rio de Janeiro: Campus-Elsevier, $2011 b$.

HERMANN, Jennifer. Reformas, Endividamento Externo e o "Milagre" Econômico (1964-1973). In: GIAMBIAGI, Fabio et al. (Orgs.). Economia BrasileiraContemporânea. Rio de Janeiro: Campus-Elsevier, 2011.

KYDLAND, F.; PRESCOTT, E. Rules rather than discretion: the inconsistency of optimal plans. Journal of Political Economy, n. 85, 1977.

LESSA, Carlos T. M. R. de. A estratégia de desenvolvimento 1974-1976 - sonho e fracasso. 1978. Tese de Doutorado, Universidade Federal do Rio de Janeiro, Rio de Janeiro.

LICHA, Antonio Luis. Teoria da Política Monetária: Uma abordagem a nível intermediário, Rio de Janeiro: Editora Alta Books, 2015.

LOYOLA, Gustavo. As relações entre a política fiscal e a política monetária no Brasil diagnósticos e propostas. In: SALTO, Felipe; ALMEIDA, Mansueto. Finançaspúblicas: da contabilidade criativa ao resgate da credibilidade. Rio de Janeiro: Record,2016.

MISHKIN, F. Inflation Targeting in Emerging Market Countries. National Bureau ofEconomic Research-NBER, Working Paper Series 7618, Cambridge MA, 2000.

MOURA, Alkimar R. Rumo à entropia: a política econômica, de Geisel a Collor. In:

LAMOUNIER, Bolívar et al. (Orgs.). De Geisel a Collor: o balanço da transição. São Paulo: Editora Sumaré, 1990.

NASSIF, André Luiz G. Há evidências de desindustrialização no Brasil? São Paulo, Revista de Economia Política, 28 (1), p. 72-96, 2008.

PASTORE, Affonso C.; PINOTTI, Maria Cristina. Demografia, reformas e bonança externa. In: Sob a Luz do Sol: uma agenda para o Brasil. Centro de Debates de Políticas Públicas, 2015.

PESSÔA, Samuel de A. Ascensão e queda da nova matriz econômica. Conjuntura Econômica. Rio de Janeiro: Editora FGV, 2013.

ROMER, David. Advanced macroeconomics. New York: McGraw-Hill, 2012. 
ROWTHORN, Robert; RAMASWAMY, Ramana. Growth, Trade and Deindustrialization. IMF Staff Papers, v. 46, n.1, 1999.

SACHS, Jeffrey D. Social Conflict and Populist Policies in Latin America. In: BRUNETTE, R.; DELARINGA, C. (Eds.). Labor Relations and Economic Performance. Londres: MacMillan Press, 1991.

SALLUM JUNIOR, Brasílio. Labirintos: dos generais à Nova República. São Paulo: Hucitec, 1996.

SALOMÃO, Ivan C.; MARQUES JUNIOR, Karlo. Duas décadas de estabilização monetária: uma análise da política fiscal e da dinâmica da dívida líquida do setor público no Plano Real. Revista de Desenvolvimento Econômico, Salvador, v. 18, n. 34, 2016.

SOLA, Lourdes; KUGELMAS, Eduardo. Política Econômica, Governabilidade e Regime Federalista. XXII Encontro anual da Anpocs. Caxambu, 1998.

TAVARES, Maria da C. de A.; ASSIS, José Carlos de. O grande salto para o caos: a economia política e a política econômica do regime autoritário. Rio de Janeiro: Zahar, 1985.

TAYLOR, John B. Discretion versus Policy Rules in Practice. Carnegie-RochesterConference Series on Public Policy, 39, pp. 195-214, 1993.

TRIBUNAL DE CONTAS DA UNIÃO. Relatório de atividades 2014. Brasília: TCU, 2015.

ZINI JUNIOR, Álvaro Antônio. A metodologia enganosa do déficit operacional. Revista de Economia Política, v. 11, n. 3, p. 104-110, 1991. 
Ivan Colangelo Salomão e Karlo Marques Junior

RESUMO

De Milagres e Espetáculos: O Ciclo Vicioso do Eterno País do Futuro

Este trabalho busca ilustrar como a adoção de políticas econômicas que privilegiem o crescimento de curto prazo para além da taxa de crescimento potencial não se sustenta do ponto de vista intertemporal. Para tanto, utilizou-se do instrumento metodológico de cotejamento de dois recentes períodos de robusto crescimento econômico na história do Brasil contemporâneo. A analogia entre o "milagre econômico" (1968-1973) e o "espetáculo do crescimento" da segunda metade dos anos 2000, os quais guardam semelhanças que não podem ser delegadas ao acaso, deve embasar a reflexão dos cientistas sociais que se dispuserem a analisar a história do país em suas múltiplas particularidades. Ao fim do período, os resultados inevitáveis são a recessão e a necessidade de um novo ajuste macroeconômico.

Palavras-chave: Economia Brasileira; ciclos econômicos; populismo econômico; “Milagre Econômico"; Nova Matriz Econômica

\section{ABSTRACT}

This paper aims to illustrate how the adoption of economic policies to achieve short-term growth does not hold intertemporal perspective. Therefore, it is used the methodological tool of comparison of two recent periods of significant economic growth in Brazilian contemporary history. The analogy between the "economic miracle" (1968-1973) and the "spectacle of growth" in the second half of the 2000s presents similarities that must be analyzed by social scientists whose purpose is to interpret Brazilian recent history. At the end of the period, the inevitable results are economic recession and the necessity of a new macroeconomic adjustment.

Keywords: Brazilian economy; economics cycles; economic populism; "Economic miracle"; New Economic Matrix 


\section{ERRATA}

Na página 735 , Onde se lia:

“http:/ / dx.doi.org/10.1590/001152582018158"

Leia-se:

“http:/ / dx.doi.org/10.1590/001152582018172"

DADOS - Revista de Ciências Sociais (2018), vol. 61, no 3: E3-E5 